\title{
The Weird 'Others': An 'Alternative' Understanding of the Witches of Macbeth from Feminist Perspective
}

\author{
Reema Chakrabarti ${ }^{1}$ PhD \& Shah Al Mamun Sarkar², PhD \\ ${ }^{1}$ Assistant Professor of English, Techno Main Salt Lake, Kolkata-70oog1, India, \\ chakrabarti.reema2012@gmail.com, https://orcid.org/oooo-ooo3-2136-7349 \\ ${ }^{2}$ Assistant Professor of English, ICFAI University Tripura, Kamalghat, West Tripura-799210, \\ India, shahalmamunsarkar@gmail.com, https://orcid.org/oooo-ooo1-9019-6577
}

\begin{abstract}
This paper attempts to re-interpret the witches of Macbeth from a Feminist perspective. Both critics as well as the ordinary readers mostly receive them in a negative light. Doing so, they overlook the fact that women like these witches are relegated to the margins and share a history of being discriminated and vulnerable to attacks. Within the text, they are humiliated as the 'weird others' and compared to 'bubbles' on earth. To this date, people have the tendency to marginalize and discriminate women who posit their individuality in their socially reclusive lifestyle. While analyzing their character from a Feminist perspective, the paper will explore their trauma and identify their mischief as a source of rebellion. By making such an alternative reading of the text, the work aims to create a 'shock-effect' among people who continue to discriminate such marginalized women.
\end{abstract}

Keywords: Women, Witches, Macbeth, Feminism, Identity.

\section{Introduction}

The online dictionary defines witches as old and ugly women who possess magical power and utilize them to attend evil ends. Whereas, the popular imagination is that the witches are the women with tremendous negative energy which they use to bewitch others and gain control over people's mind. However, from a more liberal perspective, the witches have also been described as individualistic women who do not abide by the popular faith; instead, they adhere to pagan beliefs and practices. Despite the freedom to lead an independent life in the contemporary democratic scenario, these women continue to feel intimidated as outcasts on whom people cast their suspicious and fearful glances. Pam Grossman validates this assumption in her article "Yes, Witches Are Real. I Know Because I Am One", by proclaiming how witches are treated as "terrifying outsiders" by the larger society. She also compares witches with the 'pariah' figure and reflects how these women have been historically discriminated and made vulnerable to attacks (Grossman 2019, para. 2).

The Shakespearean era has been one of the worst phases for the witches. King James VI of Scotland (King James I of England), the ruling Monarch at the time of creation of Macbeth, was extremely threatened by the notion of witches who were treated as negative forces that appeared in the form of disgusting old women with a taste for malevolence. In his book, Daemonologie (1597), the king writes that a group of witches had made an attempt to drown and kill him while he was sailing in the sea. It is worth mentioning here that King James I considered the 'witches to be real women capable of supernatural harm.' He believed that these women became witches because of the "thirst

(C) AesthetixMS 2021. This Open Access article is published under a Creative Commons Attribution Non-Commercial 4.0 International License (http://creativecommons.org/licenses/by-nc/4.o/), which permits non-commercial re-use, distribution, and reproduction in any medium, provided the original work is properly cited. For citation use the DOI. For commercial re-use, please contact editor@rupkatha.com. 
of revenge, for some tortes deeply apprehended: or greedy appetite of geare, caused through great pouerty (James I 1966, 8)". To him, such women were seekers of vengeance who manipulated and tortured people of the larger society. They considered the ordinary people to be responsible for their impoverishment and lack of fulfillment. The king's fear grew so strong that during his reign, thousands of people of Scotland were put on trial for practicing witchcraft in the country (Atherton 2017, para.3). Particularly, in 1604, under his rule as king of England, Wales and Scotland, witchcraft was made a capital offence. Anybody who was found practicing witchcraft could be executed. Henceforth, the old, poor and unprotected women who mostly lived at the edge of society became vulnerable target of the dominant class that stereotyped them as witches.

Unlike those days, in the present circumstances, feminist and postcolonial critics are more empathetic towards such marginalized beings. However, their multiple theoretical and sociological approaches could not completely evade the aspects of discrimination and oppression from our society. Any problem cannot be dealt in isolation and it is important that one studies the historical processes that generate a particular representation of any being. The Shakespearean witches in general and the witches of Macbeth in particular were not an immediate creation. Rather, their conceptualization can be sourced back to ancient history. A close analysis can help one to identify how the characteristics of the witches were associated with the different myths that led to the discrimination of such women. Multiple critics have analyzed the witches of Shakespeare. However, mostly, those analyses are restricted to their functioning as darker elements in the plot. Trent Lorcher in his essay, "Witch Symbolism in Macbeth", explains how the witches function as darker symbols of the human soul. He also explains that they are external evil forces that tempt human towards misdeeds (Lorcher 2010, para. 2). Such an assertion relates to Pam Grossman's claim on how witches are treated as fearful beings outside the realm of the society (Grossman 2019, para. 15). Even other notable critics have also treated the witches as harmful miscreants who seek fun out of others pain. The critic Daniel Albright asserts that the witches of Macbeth are basically wicked manifestation of 'multiple Satan in drag' posing threat to the entire humanity. They do not even hesitate to bargain with Satan to get what they want (Albright 2005, 226). Even female critics like Carol Atherton also claim that the witches are an evil force in the plot and their characters perfectly synchronize with the myths surrounding the witches in those days (Atherton 2017, para. 4).

However, none of the analysis introspect the exploitation faced by them. This paper, unlike the previous ones, seeks to examine the witches as exploited beings that perform mischief to gain greater significance rather than fun. .

\section{Objectives of the Article}

This paper aims to deconstruct the character of the witches and understand their role in terms of their existence in the society. Their role as catalyst to the fatal events of the plot of Macbeth can be judged as a part of their political commitments towards 'Feminism'. Though this theory was developed much later, the witches were clearly ahead of their time and were discriminated in the Shakespearean era for their unconventional attitude. For being different, they were marginalized and thus, in constant tussle with the mainstream society for their survival and identity. In this regard, it will be noteworthy to highlight that women who practice Feminism or follow an unconventional lifestyle are still discriminated by the people of mainstream society. An understanding witches' role will generate greater empathy for such marginalized women who at times undertake aggressive and rebellious stand to proclaim their identity amidst others. The paper does not limit to the understanding of the three weird sisters. It also brings within its purview an analysis of the treatment of Lady Macbeth and Hecate in the text. None of these women restrict 
themselves to the feminine roles conferred by the patriarchal society, and hence are considered evil. Their analysis from the contemporary political perspectives will perhaps generate greater sympathy among the readers who tend to stereotype such women in their limited sphere.

\section{An 'Alternative' Understanding of the Witches of Macbeth in Feminist Perspective}

Taking a feminist stand, one may assert that any unconventional woman who doesn't fit within the stereotyped framework of the patriarchal society or who is not conditioned and socialized in accordance to the norms of the patriarchal society becomes a witch by the popular understanding. People are scared of such women and often avoid them. The three weird sisters, Hecate and Lady Macbeth have been condemned as villains in the play just because they do not abide by the patriarchal strictures of femininity. Toril Moi in her Essay, "Feminist, Female, Feminine" explains how feminine and female relates to woman's biological self and her adherence to the culturally defined roles; while feminist is a political position. (Moi 1989, 117-132). The fact that they cannot be categorized as female or feminine naturally categorizes them among feminists who are politically active by nature. The three weird sisters possessed beard, Lady Macbeth and Hecate were unnaturally cruel. People often consider such features to be instances of their denial of womanhood. Actually, these women were not limited by the patriarchal constrains. It naturally opens the scope for analysis of their character from a Feminist point of view. These women were politically aware and intelligent enough to know how to motivate the powerful men for a particular action. In the era of Shakespeare, such women were ostracized by the society and forced to live in the periphery. Despite being relegated to the margins, the witches do not accept defeat at the hands of the 'civilized' men. Even as they face such discrimination, they chose to stay united with each other. Their union helps them to gain greater significance since together they could better contrive the happenings of the masculine world.

Women are often criticized for not bonding well with each other. Their weakness is attributed to the lack of unity among themselves. In fact, it is also said that this internal disunity develops their affinity to the patriarchal society that further renders them weak. In this regard, Lois Tyson in his Critical Theory Today asserts that women owe their allegiance more towards men from the same class rather than with women from different classes (Tyson 2006, 97). Also, Marion A. Davies in her essay entitled "A Brief Look at Feminism in Shakespeare's Macbeth" mentions that "women remain isolated which prevent them from making significant changes because they have no strength in size" (Davies 2009, para. 3). The activities of the weird sisters are clearly opposed to such assertions on womanhood. They enhance and proclaim the power of togetherness in Macbeth, Act-I, Scene III, lines 33-38 by singing the following:

The weird sisters, hand in hand,

Posters of the sea and land,

Thus do go about, about:

Thrice to thine and thrice to mine

And thrice again, to make up nine.

Peace! The charm's wound up. (Shakespeare 2019, 15)

It is not only the witches who are united among themselves. Even some other women in Macbeth like Lady Macbeth and Hecate are more united with womankind than men. The class difference among them does not seem to matter as they continue to seek union and gain strength from each 
other. Thus, in Macbeth, Act I, Scene-V, lines 44-46, Lady Macbeth invokes the spirit of the witches for deriving greater potency to fulfill the political ambitions of her husband; and thus she utters"Come, you spirits/ That tend on mortal thoughts, unsex me here,/ And fill me from the crown to the toe top-full/ Of Direst cruelty!" (Shakespeare 2019, 26) The witches are not only united among themselves, but they also display similar allegiance towards Hecate who belongs to a higher rank. Without any hesitation, the weird sisters abide by Hecate's instructions of misleading Macbeth. Instead of resenting her orders, the First Witch, in Macbeth, Act III, Scene V, line 37, says- "Come, let's make haste" (Shakespeare 2019, 75). Even Hecate, who was initially disappointed by the action of the three sisters, later, in Macbeth, Act IV, Scene-I, line 39, commends their hard work by saying, "O well done! I commend your pains" (Shakespeare 2019, 79). The notable feminist critic, Hélène Cixous in her essay "The Laugh of the Medusa" states- "there always remains in woman that force which produces/is produced by the other- in particular, the other woman" (Cixous 1976, 881). Perhaps, she means that women have potential to proclaim their individuality which can be enhanced if they unite and overcome the barriers of hatred among each other. By adhering to the same philosophy, the witches of Macbeth prove themselves to be natural feminists. Unfortunately they appeared before their time and thus were discriminated and criticized.

In the opening scene of Macbeth, lines 1-2, the witches utter- "When shall we three meet again/ In thunder, lightning or in rain" (Shakespeare 2019, 9). For generations, readers and audiences have criticized these witches; and like Banquo have considered them to be "instruments of darkness" (Shakespeare 2019, 20). Such critics often ignore how fearless these witches are! In the next scene, everyone exalts Macbeth for displaying super-humanly skills and bravery at the battle-field. Perhaps such dualistic interpretation occurs because men have always been kept at the centre of any power discourse. Ralph W. Emerson conceptualizes men as 'figurative warriors' (Emerson 1841, 2) who can be conventionally set apart from the other categories of people- the minors and the invalids. In the context of the play, the witches become natural invalids. Firstly, they are not men. Moreover, they are also old and haggard who live at the societal periphery. Naturally they gain the status of invalids who are not paid any respect. Instead of applauding their bravery, people reprimand them for their darker pursuits. Being debunked by the larger society, they feel disgraced and find solace in the adaptation of Feminist principles. It helps them to exalt their own power that others fail to recognize-

Stands Macbeth thus amazedly?

Come, sisters, cheer we up his sprites,

And show the best of our delights:

I'll charm the air to give a sound,

While you perform your antic round:

That this great king may kindly say,

Our duties did his welcome pay. (Shakespeare 2019, 84)

Even Lady Macbeth's ambitious designs can be studied as her efforts to validate her cultural self in a world that treats women as minor. The men in the plot often ignore her mental strength and spirits. Thus, Macduff tells her: "O gentle lady,/'Tis not for you to hear what I can speak:/ The repetition, in a woman's ear,/ Would murder as it fell” (Shakespeare 2019, 47). Further, she is also invalidated by her husband whom she had formerly assisted in gaining kingship. While planning the murder of Banquo, Macbeth tells her- "Be innocent of the knowledge, dearest chuck" (Shakespeare 2019, 63). In his essay, "Self-Reliance", Ralph W. Emerson posits the superiority of 
masculine self as opposed to the 'invalids' (Emerson 1841, 3). However, as per his argument men need to develop 'spiritual, psychological and intellectual self-formation'. Despite, this point, he places a lot of importance on 'the body'. For him, the body is an instrument that specifies the difference between a validated cultural self as opposed to the invalid cultural other. Perhaps, Lady Macbeth and the witches are not included among the valid ones because of their inferior embodiment'. This inferior physical formation leads men to ignore all other aspects of their intelligence or spiritual strength. Consequently, such social exclusion pushes these women towards a direction from where they manipulate men and play with their identities in the political realm.

The witches are deprived of their basic rights to live because of their bodily features which are different from the common mass and deemed undesirable. It is quite evident that these witches were extremely evolved at the spiritual, intellectual and psychological level. Both, Macbeth and Banquo become enthralled by the sorcery skills and seek to know more about their future. However, even while approaching the witches, the two men do not refrain from insulting them. Banquo says:

What are these

So wither'd and so wild in their attire,

That look not like the inhabitants o'the earth,

And yet are on't? Live you? Or are you aught

That man may question? (Shakespeare 2019, 15-16)

In the above lines, Banquo asserts his power to question the appearance of foreign-looking women. He does not care for the fact that the witches feel offended by his remark. Charles Lamb and Mary Lamb, in Tales from Shakespeare comment how the witches were "seemingly offended" by such connotations (Lamb and Lamb 1807, 109). As they remain quite by placing their choppy fingers on their 'skinny lips', Banquo further questions their woman-hood by pointing at their beard (Beard is a symbol of manliness in general perception. Beard in women's face is something unnatural. Therefore, being bearded witches becomes a matter of speculation). In this regard, Rosemarie Garland-Thomson in her thesis- "Aberrant Bodies: Making the Corporeal Other in Nineteenth- and Twentieth-Century American Cultural Representations" reflects how the particularities of the human body are incarnated with meanings (Thomson 1993, 2).On the basis of these meanings, social identities and relations are created. These relations in turn determine how people behave with certain groups and communities in the society. These women are mistreated and insulted repeatedly by the social men. No matter how much they protest, their social position is likely to remain constant without any improvement. Resultantly, they chose to remain silent over issues concerning themselves. However, by evoking a corporeal form, they attract the interest of people like Macbeth. Intrigued by their sorcery skills, he begins to esteem them as guides who can anchor the formation of the masculine social identity (Thomson 1993, 2). However, such notions by these men give only a precarious position to the witches in the society. They take up every opportunity of this position and behave like "connoisseurs" (Albright 2005, 226) directing the functions of the masculine world. Though, they still remain socially downtrodden, yet are able to enjoy the upheaval created in the patriarchal society that brings respite to their angst.

Their angst against the ruling men is further intensified because of the various stigmas and myths that are imposed on them by the patriarchal men and are perpetrated by the common mass. Certain other instances from the play would help the readers to identify how witches were constantly denied respect from people at the mainstream. Their subsequent repercussion will also seem justified in the context. They were compelled to live far away from the human dwelling and often 
restricted from coming closer to human civilization. Naturally, they had to choose secluded places such as deep forest, caves and heath. According to Michel Foucault individuals are sites where discourses are played out' and identity of a subject is determined by "effect of discourses and power relations" (Mills 2003, 97-98). Looking at the condition of the witches, people of the patriarchal mindset, perhaps, created a set of discourse to define and project them as inferior and powerless creatures that exist at the other end of the socially dominant forces. Being perpetrators of such mindset, the common people believe such witches to be redundant creatures. As a result, even the women of the society insult the 'witches' for no real reason.

In Macbeth, Act-I, Scene-III, line 7, the first witch, perhaps out of hunger, asks for some chestnuts from the wife of a sailor. However, the woman rebukes her by saying- "Aroint thee, witch" (Shakespeare 2019, 14) and denies from offering her the same. From the woman's reaction, it becomes apparent that she does not even consider the witch to be worthy enough for some food. Even a female critic of the present era, Carol Atherton, in her essay- "Character Analysis: The Witches in Macbeth", depicts the witch's desire for some food to be a "gluttonous demand" (Atherton 2017, para. 4) on her part. Such an analysis in the contemporary context demands urgent attention from the feminists for a revision of their character. It seems that, for centuries, they have been left in their darker zones because readers and audiences did not find them worthier than "bubbles" (Shakespeare 2019, 17). By referring to bubbles, Banquo indicates at the insignificance of their existence. Similarly, people have also ignored their characteristics and have never done any serious analysis of the same. Perhaps, people are even scared of the witches and want to stay away from their influence. Foucault also mentions that any kind of mental illness occurs as an effect of social contradictions in which some people are historically alienated (Mills 2003, 98). It may also be possible that the common mass from the mainstream society have identified the existence of some kind of mental illness among these witches. Those which are likely to arise from prolonged history of social alienation that was imposed on them. It seems that people of the present generation too have not overcome the anxiety of their being. And thus, Carol Atherton too exclaims her horror at the witch's desire for revenge which she finds to be "disproportionately cruel" (Atherton 2017, para. 4).

However, in our view, such illness can also be studied as a source of strength. One should not overlook how the witches have gained power and dark knowledge from the caves in which they dwell. These caves are the places that function as "great antechambers of the mysteries of transformation" (Gubar \& Gilbert 1979, 95). It means that such caves are a source of dark knowledge and so promote the gradual evolvement of women into powerful beings. In their book, Madwoman in the Attic, Sandra Gilbert and Susan Gubar further mention of women whose entrapment in the dark caves has led them to access the immense sources of "dark knowledge" (Gubar \& Gilbert 1979, 95) with which they weave destinies of people and cast dreams and illusions. Since the witches are more united with the womankind, they choose the sailor, instead of his wife to avenge for their insult. They do not derive their power from the surface level knowledge of the world, but from the hidden depths of their caves. Hence, they choose a sieve to reach Aleppo to find the husband and avenge the insult. However, instead of losing the bark of his ship, they use their power of the natural forces to twist it by a storm: "Though his bark cannot be lost,/ Yet it can be tempest-tost" (Shakespeare 2019, 15). It suggests that the power of the witches is mainly hallucinatory in nature as they only possess the power to influence the natural elements and not cause any real destruction. It can be possible that by projecting such a trope, Shakespeare is urging his audience to look into the "positive mythic possibilities" (Gubar\& Gilbert 1979, 95) that these women can incur- if they are given a valuable position in the society. Gubar and Gilbert too feel that such women who have been 
'imprisoned' for years in the caves possess metaphorical potential to induce beneficial and mystical possibilities.

Another feministic attribute of the witches can be traced from their use of a poetic language. In Macbeth the language used by the witches is different from the language used by the other characters in the play. They speak mostly in rhyming couplets like "Double, double toil and trouble;/ Fire burn and cauldron bubble" (Shakespeare 2019, 78). Whereas, the other characters of the play use blank verse while speaking. Shakespeare has mainly used prose, rhyme and blank verse to incur different effects in the audience. While prose and blank verse have been employed to generate seriousness of the character's speech, rhyme is mainly used to present a "ritualistic choral effect" (Schwartz 1996-2005, para. 5) assigned to such inferior characters as the witches of Macbeth or the fairies of A Midsummer Night's Dream. In a tragedy of the stature of Macbeth, the singing and dancing of witches tend to bring in comic effect with an edge of darkness to it. In this regard Diane Purkiss argues that such elements are extremely embarrassing and so the modern productions tend to dismiss those (Purkiss 2016, para. 11). However, from a feminist view-point, as of the view of Hélène Cixous, the language of women ought to be different than those of men. Such form of language might seem bizarre in comparison to the male-centric language that is stable with fixed meaning. However, women deal with the elements of fantasy and imagination by using the language of poetry that is nearer to the unconscious, and holds double meaning which very often is closer to their own sexuality (Cixous 1976, 881). These witches too exploit the aspect of double meaning imbibed in the poetic language and confuse Macbeth by using the same. They create a facade of rituals to enthrall men like him who are unable to understand the hidden meaning. Doing so, they play with masculine identities and can reduce their own anxiety for having unstable identity. Such games also help them to gain more significance in the patriarchal setup. In this regard, the position of the witches can be compared to the women writers of the contemporary generation who create their own language to not only voice their angst but also to establish their identity amidst the patriarchal set-up. For them, Gilbert and Gubar state "The women writers' own anxieties about her equivocal position in a patriarchal literary culture which often seems to her to enact strange rituals and speak in unknown tongues" (Gilbert and Gubar 1979, 95).

Cixous also claims that the motherly body of women guides them as an influential force while asserting identity. In her Feminist essay- "The Laugh of Medusa", Cixous urges women to trust other women and form such bond with each other that is capable of evoking motherly strength in them (Cixous 1976, 881). Similar evocation of motherly strength can be witnessed when Lady Macbeth invokes the witches for greater strength by evoking the tropes of motherhood. In Macbeth, Act-I Scene-V, lines 51-52 Lady Macbeth proclaims her desire to unite with the spirit of the witches to fulfill her ambition and write her own destiny. In doing so, she too invokes her motherly body by uttering- "Come to my woman's breast,/ And take my milk for gall" (Shakespeare 2019, 26). In the context of Feminism, one can interpret Lady Macbeth's words as an invocation of motherhood. In the process, she also surrenders herself to the other powerful women of this play. According to Cixous, such an act becomes instrumental in claiming one's feminist identity as it helps women to gain possession over their body. She claims that women's bodies are direct basis for female speaking. "White ink" is a metaphor for the good mother's milk that helps her in asserting significance as it stands for connection and wholeness (Cixous 1976, 881-882). However, it cannot be ignored that Shakespeare has presented this gesture of Lady Macbeth as a villainous feature. Perhaps, to suit the taste of Elizabethan audience, he portrays an ambitious and assertive woman as a destructive fiend. In this way, he warns his women audience from embracing such aspects of feminism. However, the witches are not bound by such social restrictions and no warning can limit their desire for self-proclamation. Since they are already rejected by the patriarchal society, they do 
not fear of becoming an outcast anymore. They dwell in caves that are 'womb shaped'. Perhaps, such dwellings nurture their motherly self with which they gain a sense of completeness. In these caves, they find small animals like toads and rats (namely Paddock and Graymalkin) that they keep as their pets and nurture by letting them feed on their blood. In those days, the witches were trialed for keeping such small animals as their pets. It was often claimed that they gained negative energy by feeding those animals. However, one can re-interpret such a claim and assert that the strength that these witches gain from nurturing such pets is not negative in nature. Rather, it is the nurturing strength of motherhood that helps them to proclaim their self. In Madwoman in the Attic, Gilbert and Gubar refer to 'the womb-shaped cave' that becomes a source of dark knowledge, power and proclamation.

The above assertions of the witches as prospective feminists can be supported by the argument that such women were progenies of a matriarchal culture where Mother Goddess was worshipped. For example Hecate is a Mother Goddess who has been treated as a devil in this plot. Perhaps, with the gradual development of patriarchal society and especially with the growth of monotheism, such matriarchs were side-lined and were treated as outcast. In such circumstances, women like these weird sisters were labeled as witches for being followers of Hecate. Initially the priestesses of Mother Goddess were reduced to the stature of midwives and herbalist. Later, such women were actively persecuted for failing to fit in the patriarchal culture. Obviously, such women underwent a lot of struggle to overcome the pains of losing identity and a position in the society. These witches might have undergone similar trauma of being outcast, ignored and infantilized. They carve and influence the masculine history because that was the only way to gain recognition. Also, they reject the masculine monotheistic religious tradition that has "restrictive gender expectations" (Krondorfer \& Hunt 2012, 195).Instead they worship and obey Hecate- who inspires them of the ways of manipulating Macbeth. Thus, dismissing every norm of the patriarchal society and religion, they embraced villainy that could immortalize them in literature. Notable critic, Peter Barry says that "the representation of women in literature is one of the most important forms of 'socialization' since it provides role models to indicate what constitutes of acceptable versions of the 'feminine' and legitimate feminine goals and aspirations" (Barry 2010, 117). By positing characters like the witches, literature preaches women regarding the types of role to be avoided.

Like the witches, Shakespeare too rejects the Christian principles of forgiving the sinner to cater to the taste of Elizabethan audience. However, instead of providing his own opinion, he brings in the character of the ancient Goddess- Hecate as the negative force that intensifies the fatal events of the plot. In Ancient Greece, Hecate was a Goddess, who used to bless people with good luck, health, wisdom and victory (Smith 1844, 346). People often used to put a statue of her at crossroads or entrance-ways to scare the evil spirits. In other words, she was a goddess of 'positive energy'. Perhaps, her status as a Pagan goddess was reduced to an inferior status with the advent of monotheism specially Christianity and more precisely the Roman Catholicism that mainly propagated Patriarchy. In Macbeth, Shakespeare too presents Hecate as leader of the negative force who hatches a plan with the three weird sisters to misguide Macbeth towards a deadly end by keeping him in illusion. To project her as a devilish being, her character has been analyzed from the Macbeth, Act-III, Scene V, line 14-33:

...get you gone,

And at the pit of Acheron

Meet me i'the morning: thither he

Will come to know his destiny: 
Your vessels and your spells provide,

Your charms and everything beside.

I am for the air; this night I'll spend

Unto a dismal and a fatal end:

Great business must be wrought ere noon:

Upon the corner of the moon

There hangs a vaporous drop profound:

I'll catch it ere it come to ground:

And that distilled by magic sleights

Shall raise such artificial sprites

As by the strength of their illusion

Shall draw him on to his confusion:

He shall spurn fate, scorn death, and bear

His hopes 'bove wisdom, grace, and fear:

And you all know, security

Is mortals' chiefest enemy. (Shakespeare 2019, 74)

Doing so, he denounces her godliness and demeans her stature by using the male centric religious perspective that causes much harm to women's body and mind across time and space. The patriarchal religion often functions to posit men at the centre by legitimizing the deadening triad of power, hierarchy and privilege (Krondorfer \& Hunt 2012, 198). These precepts have been precisely used by Shakespeare who derogates Hecate to the position of a witch.

\section{Conclusion}

Shakespeare continues to be lauded as people find his creation to be eternally relevant. An understanding of Macbeth's conclusion also confirms to the fact that the 'morality' which he affirms by the end of the play is not far removed from the ever-existing politics of society. According to Peter Hall (Director of Royal Shakespeare Company from 1960-68), Shakespeare brings in harmony by arranging the different classes of the society in their proper order whereby "man is above beast, king is above man and God above king" (Hall quoted in Alan Sinfield 1994, 182). Sinfield, however, finds such an order to be disturbing in nature since it is based upon 'hierarchisation' and oppression of the weaker one. Sinfield is also critical of Peter Hall's point of view that preaches to avoid 'revolution' since it causes 'anarchy' (Sinfield 1994, 184). The play Macbeth needs reconsideration since it too reinforces this popular view. The violent retribution of Macbeth was perhaps showcased to discipline the audience/readers and prevent them from mingling with such deviant women.

A society that is strictly divided into hierarchies needs unanimous and docile citizens. In such circumstances, people who exhibit deviant characteristics are discarded from the mainstream society. From an Indian perspective, one can easily identify the similarities of the witches with the transgender community. Their typical attributes like lack of a fixed gendered identity and alienation from the mainstream society are similar to that of the witches. Once, they too held 
powerful position as royal bodyguards. The changing socio-political scenario diminished their stature gradually and in the present situation, they have no real power as such. Article 377 that has been altered only in the recent years once condemned their position as illegal. At a social level, they still continue to be discriminated. Most people from transgender community also fail to revolt against the situation. Instead, they simply bad-mouth people and curse them to overcome the feeling of angst inside them. The witches are, nothing more than the metaphorical representation of those who are similarly marginalized for their distinct behavior outside the gendered binaries. The history of the world reveals how the people have taken such Shakespearean ideology a long way. Since these have now become deeply imbibed in our mind and culture, the multiple laws favoring the marginalized, have hardly helped in eradicating oppression and discrimination. The situation of the Black Americans can be taken up as another such example. The paper has repeatedly connected the witches' mischief to the rebellion of the suppressed classes. Doing so, it aims to caution readers from continuing such oppression on marginalized beings.

\section{REFERENCE}

Abrams, M.H. and Harpham, G. G. (2008). A Glossary of Literary Terms, 9th Edition. Boston: Wadsworth Cengage Learning.

Albright, D. (2005). “The witches and the Witch: Verdi's Macbeth.” Cambridge Opera Journal, vol. 17, no.3, pp. 225-252. doi:10.1017/So954586706002059

Ashcroft, B, Tiffin, H and Griffiths, G. (200o). Post-colonial Studies: Key Concepts. London and New York: Routledge.

Atherton, Carol. (19 May 2017). "Character Analysis: The Witches in Macbeth.” The British Library, The British Library. Retrieve from www.bl.uk/shakespeare/articles/character-analysis-the-witches-inmacbeth.

Barry, P. (2010). Beginning Theory: An Introduction to Literary and Cultural Theory. New Delhi: Viva Books.

Brown, P. (1985). "'This thing of darkness I acknowledge mine': The Tempest and the discourse of Colonialism."Political Shakespeare: New essays in cultural materialism. Ed. Jonathan Dollimore and Alan Sinfield. Ithaca and London: Cornell University Publication, pp. 48-71.

Burkert, W. (1987). “Hecate.” Greek Religion: Archaic and Classical. Oxford: Blackwell Publisher.

Chaundy, B. (30 October 2009). “The Burning Times.” Retrieved from http://news.bbc.co.uk/2/hi/uk_news/magazine/8334055.stm\#: :text=In\%2omainland\%2oEurope\%2oan d\%2oScotland,the\%2oDevil\%2oor\%2ohis\%2oservants.

Cixous, H. (1976). “The Laugh of the Medusa.” Trans. Keith Cohen and Paula Cohen. Signs Vol. 1, no. 4, pp. 875-893. http://www.jstor.org/stable/3173239

Davis, M. A. (2009). "A Brief Look at Feminism in Shakespeare's Macbeth.”Inquiries Journal/Student Pulse vol. 1., no.11. Retrieved from http://www.inquiriesjournal.com/a?id=1691

Emerson, R. W. (1841). “Self-Reliance.” First Series. Retrieved from https://emersoncentral.com/ebook/SelfReliance.pdf

Gilbert, S. M. and Gubar, S. (200o). The Madwoman in the Attic. New Haven and London: Yale University Press. 
Gramsci, A. (1971). Selections from the Prison Notebooks. Ed and trans. Quintin Hoare and Geoffrey Nowell Smith. London: Lawrence and Wishart.

Grossman, P. (May 30, 2019). "Yes, Witches Are Real. I Know Because I Am One.” Retrieved from https://time.com/5597693/real-women-witches/

“HEKATE.” HECATE (Hekate) - Greek Goddess of Witchcraft, Magic \& Ghosts, www.theoi.com/Khthonios/Hekate.html.

King James I. (1966). Daemonologie. Edinburgh: Edinburgh University Publication.

Krondorfer, B \& Hunt, S. (2012). Introduction: Religion and Masculinities - Continuities and Change. Religion and Gender. Vol. 2. Pp. 194-206. 10.1163/18785417-00202002.

Lamb, C and Lamb, M. (2006). Tales from Shakespeare. Kolkata: Book Club.

Louai, E. H. (January 2012). "Retracing the concept of the subaltern from Gramsci to Spivak: Historical developments and new applications."African Journal of History and Culture (AJHC). Vol. 4, no. 1, pp 48. doi: 10.5897/AJHC11.020

Lorcher, T. (13 Jan. 2010). "Macbeth Study Guide: Witch Symbolism and Other Symbols." BrightHub Education. Retrieved from www.brighthubeducation.com/homework-help-literature/61498-symbols-inmacbeth/.

Mills, S. (2003). Michel Foucault. London and New York: Routledge.

Moi, T. (1989). “Feminist, Female, Feminine.” The Feminist Reader. Eds. Catherine Belsey and Jane Moore. New York: Basil Blackwell, pp. 117-132.

Newport, S. E. (2018). “Writing Otherness: Uses of History and Mythology in Constructing Literary Representations of India's Hijras". Thesis. University of Manchester (School of Arts, Languages and Cultures).

Proletariat, W. (1 June 2016). “Celebrating Shakespeare: a Marxist-Leninist Perspective.” The Communists,. Retrieved from https://thecommunists.org/2016/o6/o1/news/culture/celebrating-shakespeare-marxistleninist-perspective/.

Purkiss, D. (15th March 2016). "Witches in Macbeth." British Library. Retrieved from bl.uk/shakespeare/articles/witches-in-macbeth

Said, E. (1979). Orientalism. New York: Vintage.

Schwartz, D. B., (1996-2005). "Shakespearean Verse and Prose.” ENGL 204/ENGL 339. Retrieved from http://cola.calpoly.edu/ dschwart/engl339/verseprose.html

Shakespeare, W. (2019). Macbeth. New Delhi: Fingerprint.

Sinfield, A. (1994). "Royal Shakespeare: Theatre and the Making Ideology." Political Shakespeare: Essays in Cultural Materialism. Ed. Jonathan Dollimore and Alan Sinfield. Ithaca and London: Cornell University Press. Pp. 182-205.

Smith, W. (1844). Dictionary of Greek and Roman Biography and Mythology, Vol-2. Edited. London: James Walton.

Spivak, G. C. (1988). “Can the Subaltern Speak?” Marxism and the Interpretation of Culture. Eds. Cary Nelson and Lawrence Grossberg. Urbana/Chicago: University of Illinois Press.

Thomson, R. G. (1993). "Aberrant Bodies: Making the Corporeal Other in Nineteenth- and TwentiethCentury American Cultural Representations.” Thesis. Brandies University.

Tyson, L. (2006). Critical Theory Today: A User-Friendly Guide. New York and London: Routledge. 
“What Do the Witches in 'Macbeth' Represent?” Reference, IAC Publishing. Retrieved from www.reference.com/world-view/witches-macbeth-represent-a7b747c49eegc783.

"Witch." Dictionary.com. Retrieved from www.dictionary.com/browse/witch.

"Witch." (20 May 2020).Wikipedia, Retrieved from simple.wikipedia.org/wiki/Witch 